\title{
An Unusual Diagnosis in a Patient with Suspected Colorectal Cancer
}

\author{
Joana Carmo $^{a}$ Susana Marques ${ }^{a}$ Miguel Bispo $^{a, b}$ Pedro Figueiredo ${ }^{a, b}$ \\ David Serrab

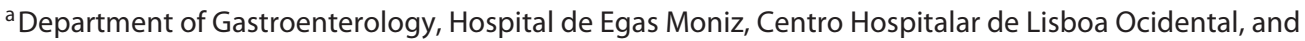 \\ ${ }^{b}$ Department of Gastroenterology, Hospital da Luz, Lisbon, Portugal
}

Keywords

Colonoscopy $\cdot$ Colorectal cancer $\cdot$ Colonic lipoma

\section{Um diagnóstico raro em doente com suspeita de neoplasia colo-rectal \\ Palavras Chave \\ Colonoscopia · Cancro colo-rectal · Lipoma do cólon}

A 78-year-old female was referred to a gastroenterology appointment due to recurrent lower abdominal pain, anorexia, and significant $(\sim 10 \%)$ weight loss over the last 3 months. Abdominal computed tomography (CT) showed a 4-cm hypodense lobulated lesion, with an eccentric solid component, in the ascending colon (Fig. 1). In colonoscopy, a large broad-based ulcerated mass, with necrotic and fatty tissue exposed in the ulcerated area, was documented in the ascending colon (Fig. 2a, b). First, this lesion was misinterpreted as an ulcerated and necrotic colonic adenocarcinoma, but biopsies were negative for malignancy. Colonoscopy was repeated and the hypothesis of a large ulcerated colonic lipoma was considered.

\begin{tabular}{ll}
\hline KARGER & (c) 2017 Sociedade Portuguesa de Gastrenterologia \\
& Published by S. Karger AG, Basel \\
$\begin{array}{l}\text { E-Mail karger@karger.com } \\
\text { www.karger.com/pjg }\end{array}$ & $\begin{array}{l}\text { This article is licensed under the Creative Commons Attribution- } \\
\text { NonCommercial-NoDerivatives 4.0 International License (CC BY- } \\
\text { NC-ND) (http://www.karger.com/Services/OpenAccessLicense). } \\
\text { Usage and distribution for commercial purposes as well as any dis- } \\
\text { tribution of modified material requires written permission. }\end{array}$
\end{tabular}

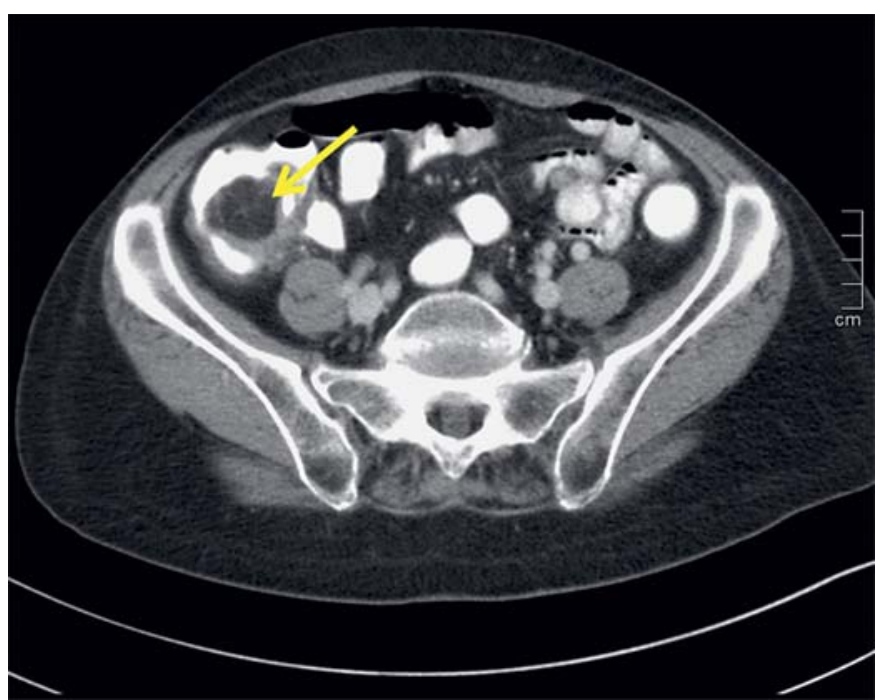

Fig. 1. Abdominal computed tomography showed a 4-cm hypodense lobulated lesion, with an eccentric solid component, in the ascending colon.

As this large and extensively ulcerated lesion was symptomatic, laparoscopic right hemicolectomy was performed. Pathological gross examination showed an ulcerated mass with a broad base, measuring $40 \times 30 \mathrm{~mm}$. The

Dr. Joana Carmo

Gastroenterology Department, Hospital Egas Moniz

Centro Hospitalar de Lisboa Ocidental, Rua da Junqueira, 126

PT-1349-019 Lisbon (Portugal)

E-Mail joanavcarmo@gmail.com 
Fig. 2. Colonoscopy documented a large broad-based ulcerated mass, with necrotic and fatty tissue exposed in the ulcerated area, in the ascending colon.
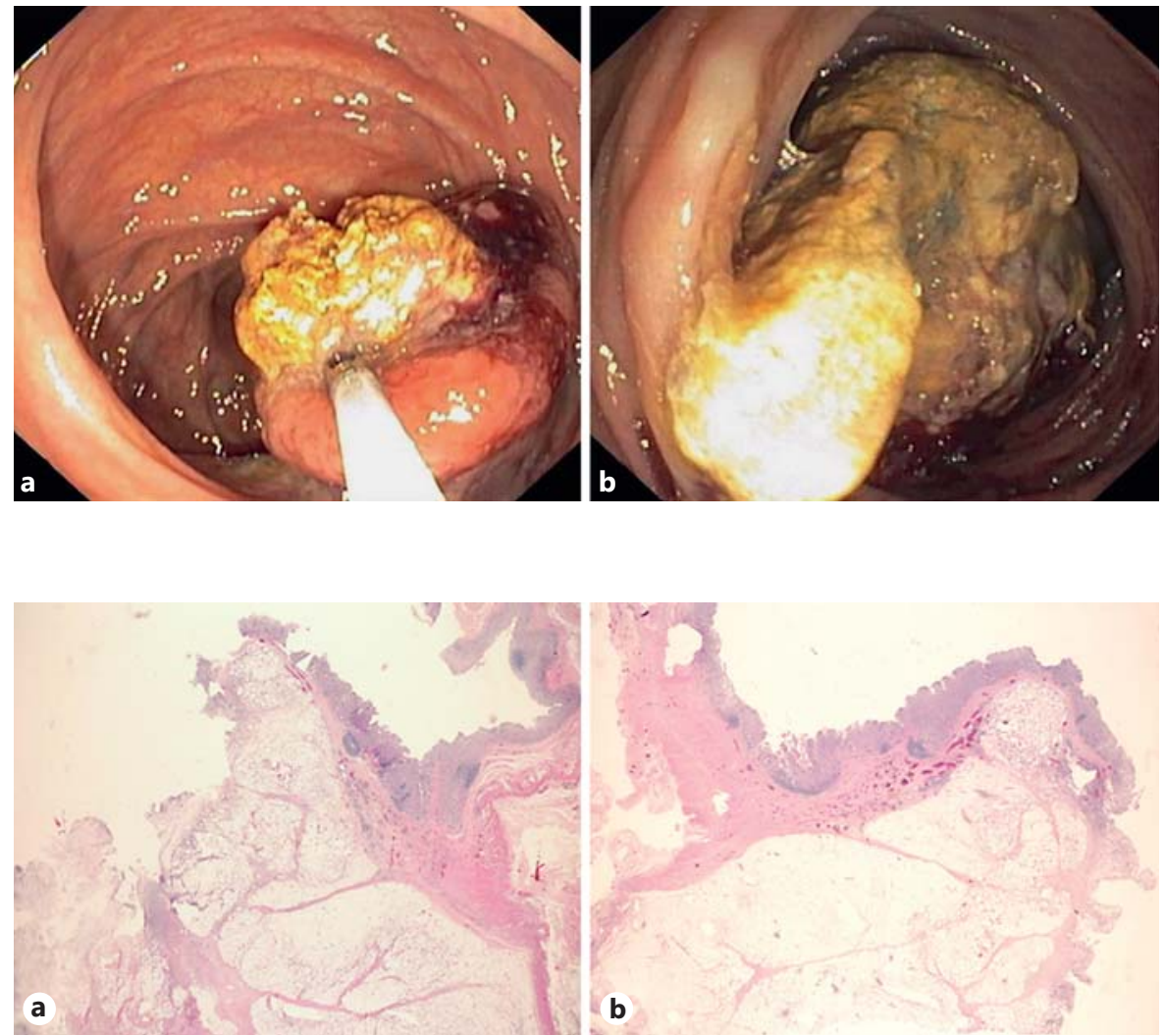

Fig. 3. Histopathologic examination revealed that the colonic mass was composed of mature adipose tissue covered by ulcerated and chronic inflamed mucosa. HE. $\times 20$. ing large colonic lipomas [2]. However, the diagnostic value of CT is limited, particularly in small lipomas [4]. Surrounding soft tissue or stool may create an artificial increase in CT density values, which can also limit its accuracy [3]. Magnetic resonance imaging may be particularly useful in the detection of these lesions, as the signal intensity is characteristic of adipose tissue on T1-weighted and fat-suppressing images [1]. Colonoscopy is generally reliable for the diagnosis of colonic lipoma. A number of endoscopic features suggestive of colonic lipomas have been described, including the "cushion/pillow sign" (indentation on gentle pressure with the tip of a biopsy forceps), the "tenting sign" (elevation of the overlying mucosa when grasped by the forceps), and the "naked fat sign" (extrusion of fat at a biopsy site) [3]. The mucosa overlying colonic lipomas is usually normal, but, in rare cases, colonoscopy may reveal ulceration, a finding that may lead to a wrong diagnosis of adenocarcinoma $[1,2]$. Asymptomatic lipomas of the large bowel probably do not need treatment, because malignant transformation has not been reported [3]. Therapy should be reserved for symptomatic lesions or for cases where exclusion of adenocarcinoma cannot be assured [3] . 
Statement of Ethics

This study did not require informed consent nor review/approval by the appropriate ethics committee.

\section{Disclosure Statement}

All authors have approved the manuscript and agree with its submission to GE - Portuguese Journal of Gastroenterology. All authors have nothing to disclose and there is no funding to declare.
References
1 Katsinelos P, Chatzimavroudis G, Zavos C, Pilpilidis I, Lazaraki G, Papaziogas B, Paroutoglou G, et al: Cecal lipoma with pseudomalignant features: a case report and review of the literature. World J Gastroenterol 2007;13: 2510-2513.

2 Meghoo C, Cook P, McDonough C, Bowser L, Waddell B: Large colonic lipoma with mucosal ulceration mimicking carcinoma. Gastrointest Endosc 2003;58:468-470.
3 El-Khalil T, Mourad F, Uthman S: Sigmoid lipoma mimicking carcinoma: case report with review of diagnosis and management. Gastrointest Endosc 2000;51:495-496.

4 Aytaç B, Yerci O, Gurel S, Ferik Z: Colonic lipomas mimicking colon cancer. Turk J Pathol 2010;26:196-199. 